\title{
7.2 До питання про можливості використання криміналістичного аналізу в розслідуванні злочинів (на прикладі серійних сексуально-садистських вбивств)
}

Здатність до аналізу не слід змішувати з простою винахідливістю, бо аналітик завжди винахідливий, тоді як не всяка винахідлива людина здатна до аналізу. Едгар Аллан По

Серед численних видів вбивств найбільшу суспільну небезпеку представляють саме серійні сексуальні (або сексуально-садисьські) вбивства, які вчиняються протягом тривалого часу (роки, десятиліття), та супроводжуються тортурами і катуванням жертв, що входить до своєрідного обов'язкового «ритуалу» злочинців. Кількість їх жертв обчислюється десятками і сотнями. Окрім цього, небезпека вказаних злочинів полягає в тому, що серійні вбивці у зв'язку із наявністю у них певних психопатологій продовжують своє «полювання» все життя і не здатні зупинитися самі.

Вказані та інші особливості серійних сексуальних вбивств, у тому числі відсутність видимого зв'язку між злочинцем і його жертвами, роблять неефективною застосування традиційної методики розслідування вбивств. Одним лише вивченням способу життя жертви та іï оточення розкрити ці злочини неможливо. Серійні вбивці-маніяки вибирають жертви лише тільки за ним самим відомими ознаками. Відповідно іншими мають бути і шляхи встановлення злочинців і методи розслідування.

Не викликає сумнівів, що у діяльності слідчого немає і не може бути місця поняттю «дрібниця». Будь-яка дрібна деталь, незалежно від того, чи є вона матеріального (предмет, річ, їх частини тощо) або іншого походження (інформація або будь-які дані про людину, їі психологічні та характерологічні особливості, звички та ін.) може стати відправною точкою для висування, перевірки або спростування версії, обрання вірного напряму розслідування або вирішальним доказом у кримінальному провадженні/справі. Саме тому потрібно вчитися розпізнавати можливі зачіпки, якими б незначними та малоймовірними 
вони на перший погляд не видавалися, ретельно їх досліджувати, творчо підходити до можливостей їх використання з метою встановлення усіх обставин злочину.

Зокрема, для вирішення проблем різної складності, що виникають в процесі розкриття i розслідування злочинів, використовується метод криміналістичного аналізу [214, с. 341].

Останніми роками науково-технічний прогрес йде стрімкими темпами: з'являються нові технічні засобі, технології, а з ними можливості передачі та обробки інформації. Злочинці активно використовують вказані можливості в своїй діяльності, що становить певні труднощі для правоохоронних органів. Проте, науково-технічний прогрес є надбанням усього людства, тому він також відкриває нові можливості у боротьбі зі злочинністю: поява нових засобів i способів виявлення, фіксації, вилучення слідів злочину і злочинця, речових доказів, і використання їх в доказуванні у кримінальному провадженні.

Однак, поряд з надбаннями науково-технічного прогресу, важливими i незамінніми залишаються перевірені часом методи роботи слідчих. Одним 3 них є криміналістичний аналіз, який, на нашу думку, можна визнати одним з тактикокриміналістичних засобів і важливою складовою тактико-криміналістичного забезпечення розслідування злочинів [215, с. 64].

Криміналістичний аналіз (далі - КА) завжди був, $є$ й надалі залишатиметься у арсеналі методів діяльності слідчого. Власне, 3 нього і розпочинається будь-яке розслідування, оскільки усталений вираз «вивчення матеріалів» кримінальної справи/провадження не обходиться без аналізу усієї наявної інформації, визначення мети і напрямів подальших дій тощо.

Поле застосування КА у правоохоронній діяльності доволі широке. Він є одним з ефективних методів роботи та інструментів слідчого: достатньо простий у використанні, такий, що завжди перебуває при слідчому, який має бути готовим до його належного застосування для встановлення усіх обставин події злочину. Аналітичні здібності слід визнати професійно необхідними якостями слідчого, без яких його розслідування будуть страждати на неповноту. 
Саме за допомогою криміналістичного аналізу матеріалів кримінальної справи/провадження виявляються недоліки розслідування: як окремої або декількох слідчих (розшукових) дій, тактичної операції, оперативно-розшукових заходів, так і організації розслідування в цілому. Розкриття злочину «слідчим шляхом» не обходиться без криміналістичного аналізу слідчим усіх матеріалів справи/кримінального провадження, повноти та якості проведення слідчих дій, їх результатів, отриманих доказів, наявної криміналістично значущої інформації.

За належного проведення результати криміналістичного аналізу можуть стати відправною точкою у розкритті злочинів і встановленні злочинців. Даний метод $є$ ефективним і має застосовуватися у кожному розслідуванні. Проте, особливо важливе значення належне його застосування набуває при розслідуванні нерозкритих злочинів минулих років, по яких КА $є$ одним 3 основних методів і з якого власне й розпочинається ця робота.

Наочніше ефективність застосування КА можна побачити на при розслідуванні серійних та серійних сексуальних (або сексуально-садистських) вбивств. Останні у своїй більшості належать до категорії «злочини минулих років», оскільки вчиняються протягом тривалого часу (місяці, роки, десятиліття) та розкриваються найчастіше випадково, через помилки злочинців, «дрібниць» при їх розслідуванні не буває. Натомість, у практиці розслідування вказаних злочинів найчастіше саме через результати докладного КА розслідування виходило на вірний напрям.

Так, наприклад, «прорив» у розслідуванні справи Міхасевіча («вітебський душитель», 36 доведених слідством вбивств) став можливим передусім завдяки аналітичним здібностям слідчого Миколи Ігнатовича, який докладно вивчив кримінальні справи про вбивства жінок в області, належним чином проаналізував наявну інформацію і зробив правильний висновок, що усі злочини вчинено однією особою. Після чого М. Ігнатович домігся об'єднання усіх кримінальних справ в одне провадження, після чого розшук злочинця набув організованого характеру і привів до встановлення і затримання серійного вбивці. (Зазначимо, що до затримання Міхасевіча за скоєні ним вбивства було засуджено 
14 чоловік: один з яких був страчений, інший - засуджений на 15 років позбавлення волі, відсидів 6 років і осліп, після чого був звільнений як особа, що не становить небезпеки для суспільства, четверо осіб провели в місцях позбавлення волі більше 10 років).

Більше того, ще до практичного застосування для розшуку серійних вбивць «психологічного портрету» (вперше у СРСР був використаний при розслідуванні злочинів Чікатіла лікарем-психіатром О. О. Бухановським), також шляхом аналізу матеріалів кримінальної справи, отриманих оперативних даних $\mathrm{i}$ повідомлень громадян слідчий власноруч склав приблизний портрет серійного маніяка (його зовнішність, род занять, наявність автівки, причетність до правоохоронних органів), який згодом повністю збігся з образом Міхасевіча.

У подальшому також шляхом аналізу матеріалів справи, оперативних та інших даних слідчий М. Ігнатович вдруге попередив ймовірну слідчу помилку, зрозумівши, що злочинець намагається відвернути увагу правоохоронних органів від Полоцька, де мешкав і працював, надіславши листа від «патріотів Вітебська», та зосередив увагу оперативно-слідчих груп саме на цьому місті.

Слідча практика розслідування злочинів даної категорії містить достатньо прикладів результативного застосування криміналістичного аналізу.

Так, аналітичні здібності та практичний досвід керівника слідчої групи I. М. Костоєва привели до успіху у справі Чікатіла. Криміналістичний аналіз злочинів О. Кузнєцова дозволив встановити важливу особливість серійного вбивці, який дотримувався певного стереотипу при виборі своїх жертв. Вказана обставина була врахована при організації та проведенні оперативно-розшукових заходів.

На жаль, достатньо і недоліків, пов'язаних із неналежним застосуванням вказаного методу. В обвинувальному висновку по справі Головкіна було, зокрема, зазначено, що «...на початковому етапі справи розслідувалися розрізнено, без врахування конкретної обстановки, оцінки доказів і аналізу (виділено нами - О.А., В.Ж.) наявних даних...Висновки слідчо-оперативних 
працівників були засновані на припущеннях або аналогії наявної практики розкриття тяжких злочинів...що ускладнило пошук злочинця» [216, с. 266-267].

Видається, що найбільш важливе значення КА при розслідуванні серійних сексуально-садистських вбивств полягає у тому, що, окрім організаційного та пізнавального аспекту (встановити необхідність і послідовність проведення слідчих дій, оперативно-розшукових заходів тощо), цей метод дозволяє побачити усі недоліки та помилки, допущені при розслідуванні, та визначити заходи і засоби щодо їх усунення та попередження у подальшому. Для цього слід знати про КА, розуміти його значення та місце у встановленні обставин події, і належним чином ним володіти.

Для ефективного здійснення вказаного методу, окрім практичного досвіду, залежно від категорії злочину, напряму та мети застосування, бажаних результатів, слідчому, працівникам оперативних підрозділів, експертам, прокурорам (процесуальним керівникам) потрібно мати певні, у тому числі спеціальні, знання. Серійним сексуально-садистським вбивствам притаманні особливості, що відрізняють їх від інших вбивств, у тому числі вчинених 3 сексуальних мотивів. Діяльність по їх розкриттю та розслідуванню також має здійснюватися по-іншому, 3 врахуванням вказаних особливостей. Це ж стосується й криміналістичного аналізу. Правильно зазначається, що «методологічну основу криміналістичного аналізу складають знання кримінології, кримінального права, теоретичних основ криміналістики» [217, с. 52].

Все вищенаведене дає підстави для певних висновків.

3 метою успішного вирішення завдань розслідування слід використовувати всі наявні і доступні інструменти/методи. При цьому слід враховувати, що найчастіше за все слідчий при аналізі наявної інформації по справі використовує власний досвід розслідування. Однак, його особистий досвід завжди обмежений лише кількістю самостійно розслідуваних злочинів та особистісними якостями слідчого. Тому при розслідуванні складних справ поряд 
3 методами суб'єктивного аналізу необхідно застосовувати інші методи наукового пізнання [218, с. 267-268].

Можна визнати за позитивне, за певний прорив, що нарешті визнано за необхідне впровадження сучасних аналітичних технологій, у тому числі кримінального аналізу, у практику діяльності правоохоронних органів, зокрема, щодо розкриття та розслідування злочинів. Однак, слід враховувати, що попри наявність інтересу до кримінального аналізу, який виник порівняно нещодавно, вказана діяльність потребує наявності фахівців-аналітиків, яких слід підготувати, навчити усім тонкощам такої роботи, забезпечити відповідними технічними засобами, програмним забезпеченням.

Також необхідно мати на увазі, що кримінальний аналіз спрямований на перспективу, його процедура потребує зусиль багатьох людей і певного часу, так само як і отримані результати повинні бути належним чином і правильно інтерпретовані фахівцями, щоб бути в подальшому успішно використані на практиці. Надалі слід оцінити результати практичного застосування, виявити його можливі слабкі сторони та поміркувати над цим.

Слід також враховувати існуючі проблеми з підготовкою таких фахівціваналітиків, розробкою відповідного програмного і методичного забезпечення, часу, який потрібен на те, щоб створити дієву та ефективну систему кримінального аналізу, запустити іï в дію, апробувати на практиці, оцінити отримані результати, використати їх належним чином і з успіхом.

Тому, попри важливість використання інших, сучасних і таких, що довели свою ефективність у діяльності правоохоронних органів інших країн аналітичних методів і методик у боротьбі зі злочинністю, разом з тим слід використовувати апробовані вітчизняною слідчою практикою методи, які в разі правильного їх застосування також можуть привести до успіху в розкритті та розслідуванні злочинів. До того ж вони є достатньо простими у застосуванні і не потребують інших здібностей, окрім аналітичних, як от криміналістичний аналіз.

Звичайно, що використання вказаних інструментів/методів потребує обізнаності та ознайомлення з їх можливостями, наявності необхідної літератури, 
методичних рекомендацій і доступу до них усіх практичних працівників, кому доводиться займатися розкриттям та розслідуванням злочинів. Проте, досьогодні бракує такої літератури, у тому числі з криміналістичного аналізу, що потребує якнайскорішого вжиття відповідних заходів щодо виправлення такого положення з метою забезпечення належних умов для ефективного розкриття та розслідування злочинів. 